\title{
Fifty years of life in classrooms: an inquiry into the scholarly contributions of Philip Jackson
}

\author{
Cheryl J. Craig (D) and Maria Assunção Flores (iD ${ }^{b}$ \\ aHouston Endowment Endowed Chair of Urban Education, Texas A\&M University, College Station, TX, USA;

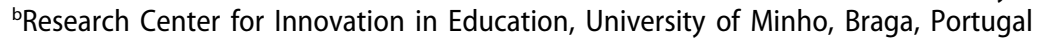

\begin{abstract}
The intent of this article is to explore the scholarly influence of Philip W. Jackson through examining the spread of his scholarship and the ideas he generated. The research design of this paper is borrowed from a previous study (Ben-Peretz \& Craig, 2018) about another distinguished curriculum scholar, Joseph J. Schwab. The work begins with a biography of Philip Jackson and continues with literature reviews on the history of ideas and the use of knowledge in education. This background is followed by a description of the study's research method, 'inquiry into inquiry', and its data sources (Scopus-listed articles, published books/ Google citations, invited addresses, transcribed interviews, conference proceedings, invited addresses, etc.) The papers' findings focus on (1) the influence of Jackson's ideas and approaches, (2) Jackson's direct impact through involvement in projects/organizations, and (3) Jackson's impact on the scholarly literature. Discussions of generative scholarship, intergenerational legacy and scholarly influence conclude the article, along with the recommendation that the 'inquiry into inquiry' approach be reenacted with other noteworthy curriculum figures to more fully understand the influence of ideas and research dissemination in curriculum and instruction/teaching and teacher education.
\end{abstract}

\section{KEYWORDS}

Scholarly contributions; history of ideas; Philip Jackson; teaching; curriculum; classroom context; contexts of teaching; John Dewey

\section{Introduction}

This enquiry examines the scholarly contributions of Philip Wesley Jackson on the occasion of the fiftieth anniversary of the release of his book, Life in classrooms (Jackson, 1968). Jackson's game-changing volume introduced the field of education to fresh ways of thinking about teachers, students and schools, championed alternate methods to conduct research and provided an avenue through which Jackson became promoted at the University of Chicago, a venerable institution long-revered as an intellectual hub of U.S. education. Since 1968, Life in classrooms has formed a marker in the educational enterprise nationally and internationally. Published in over 10 languages (Cunningham, 2015), the volume is read as part of almost every curriculum and instruction graduate programme worldwide. Torres (1991a), in his Foreword to the Spanish edition of the book, La vida en las aula (first edition in 1991, reprinted in 1992, 1994, 1996, 1998, 2001), asserted that the book remains innovative in so far as the author reflects on what really happens inside classrooms, thus making the volume a hallmark for those beginning qualitative research in education. 
The decision to write this article emerged on the eve of a Portuguese conference that honoured Philip Jackson's contributions to understanding life in schools, a meeting that focused on the influence he had on Spanish and Portuguese teaching and teacher education. Maria Assunção Flores organized the institute; Cheryl J. Craig and Maria Assunção Flores respectively delivered opening and closing addresses; and Maria Inês Marcondes from Brazil served as the discussant for both lectures. In preparation for their keynote speeches, Craig read all of Jackson's English scholarship and Flores read all of his translated French, Spanish and Portuguese works. Each additionally conducted interviews with others who either knew Philip Jackson personally or were affected by his scholarship. Given our extensive preparation for the lectures, we (Craig and Flores) decided that a memorial paper should be written showcasing Jackson's cumulative achievements. Both of us were very much affected by Jackson's work, particularly by the book Life in classrooms. Cheryl Craig became introduced to Philip Jackson's scholarship in the 1980s while enrolled in a Master's degree program at the University of Calgary in Canada. Later, when she completed her doctoral degree at the University of Alberta, Jackson and his groundbreaking book, Life in classrooms, were foundational to the conceptual frame of her dissertation study, Coming to know in the professional knowledge context (Craig, 1992). Since then, Jackson's scholarship has more-often-than-not been cited in Craig's publications, most notably in her American Educational Research Journal article, 'Why is dissemination so difficult? The nature of teacher knowledge and the spread of curriculum reform' (Craig, 2006). As for Maria Assunção Flores, she first became acquainted with Jackson's work in the early 1990s when she was a Master's degree student at the University of Minho, Portugal. That learning (Flores, 1997) subsequently informed her doctoral research program at the University of Nottingham in England. Flores' reading and re-reading of Jackson's scholarship in four languages (Portuguese, Spanish, French, English) shaped-and continues to shape-her ways of doing research and of looking at classroom ecologies within a dynamic, complex, creative and holistic system that moves beyond the sometimes obvious, visible and taken-for-granted.

Both authors were fortunate enough to attend the last speech given by P.W. Jackson at the annual meeting of American Education Research Association (AERA) held in Philadelphia in 2014. On that occasion, Jackson revisited his academic life and work and challenged audience members with his insightful and critical views about teaching and doing research. Maria Inês Marcondes also attended Jackson's final lecture and recalled that:

\footnotetext{
... what was most important in Jackson's presentation at AERA (unfortunately, his last one) was his capacity to present and problematize his findings showing to us the provisional character of research and keeping his mind open to new challenges. Jackson showed us how researchers must doubt their own theories. For me, this was the most important lesson I have learned from Jackson-the academic-who presented to us what schools really do (Marcondes, 2018, personal communication/interview).
}

Cheryl Craig proposed that we adopt the framework of an article that Miriam Ben-Peretz and she had previously authored on the spread of Joseph J. Schwab's ideas and influence (Ben-Peretz \& Craig, 2018) because it suggested others employ the same framework to explore the impact of other prominent educational leaders. These were the combined circumstances that lay in the background and gave rise to this article examining Philip W. Jackson's professional impact and the dissemination of his ideas in English, Spanish, Portuguese and French, among other languages.

As foreshadowed, the framing of this article closely follows the one that Ben-Peretz and Craig created. Therefore, we begin with a bio-sketch of Philip W. Jackson, break into our literature review and research method and then spotlight six themes that emerged in Jackson's body of work. We end with an analysis of Jackson's contributions to the field of education five decades after-the-fact.

\section{Biography}

Philip Wesley Jackson was born in 1928 and was adopted by a New Jersey farming family. Early on, he displayed a talent in music and reciting poetry. He became a snake charmer in 
a Vaudeville act at 6 years of age. After high school, Philip Jackson served in the U.S. Navy. He next attended New Jersey State Teachers College in Glassboro ${ }^{1}$ (now known as Rowan University) from which he graduated in 1951 and, at a fellow sailor's urging, continued on to Temple University, where he received his Master's degree in 1952. He then entered Columbia University where he earned his doctoral degree in 1955 (American Educational Research Association E-Newletter, 2015). At what-is-now Rowan University, he was introduced to John Dewey's philosophy. Dewey continued to form a sustained presence in Jackson's studies and life. Jackson became Principal of the University of Chicago's Nursery School from 1967-1970. From 1970-1975, he was the Director of the Laboratory Schools that John Dewey founded. Philip W. Jackson was a past president of the John Dewey Society (1996-1997), a past president of the American Educational Research Association (AERA) (1989-1990), an editor of the Handbook of Curriculum (Jackson, 1990) and the David Lee Shillinglaw Distinguished Service Professor Emeritus of Education and Psychology at the University of Chicago.

\section{Theoretical framework}

Two broad concepts inform our enquiry into Jackson's achievements and impact: 1) the history of ideas, and 2) the use of knowledge in education.

\subsection{History of ideas}

This enquiry into Jackson's intellectual heritage and its transmission across people and time is nested in the history of ideas. Multiple definitions of the term 'ideas' can be found in the literature as well as multiple approaches to investigating their history. Ideas, in Lovejoy's view,

... are the most migratory things ... A preconception, category, postulate, dialectical motive, pregnant metaphor or analogy, 'sacred word', mood of thought, or explicit doctrine, which makes its first appearance upon the scene in one of the conventionally distinguished provinces of history may ... cross over into a dozen others" (Lovejoy, 1940, p. 4).

He continued:

An idea ... is ... a stubborn thing; it commonly has its own 'particular go'; and the history of thought is a bilateral affair-the story of the traffic and interaction between human nature, amid the exigencies and vicissitudes of physical experience, on the one hand, and on the other, the specific natures and pressures of the ideas which men [sic] have ... admitted to their minds (p. 23).

Lovejoy developed twelve categories to study cultural and intellectual history (Lovejoy, 1940, pp. 11-12), one of them being ideas in education.

Several basic approaches characterize the history of ideas. Lovejoy favoured 'unit ideas', major concepts that trickled into diverse disciplines (i.e. evolution) and suggested that interdisciplinary studies are needed to follow their development. Another approach focuses on 'context' as determining the meaning of any given text and, therefore, the study of context is necessary for understanding the history of ideas. A number of studies have focused on individual scholars and followed their development of ideas and their impact (Palmer, 2001). This study is of this latter variety.

An interesting point concerning the history of ideas was put forth by Reid (1993). He opined that 'accounts that present a history of ideas can stress continuity or discontinuity, evolution or revolution' (p. 84). These considerations additionally will be pondered as Jackson's scholarship is analysed.

\subsection{Use of knowledge in education}

Readings exist about the dissemination and use of research knowledge in education (i.e. Fuhrman, 1994; Hemsley-Brown \& Oplatka, 2005; Huberman, 2002). Attention has also been drawn to the nature of paradigms in research (Lincoln \& Guba, 1985) and the phenomenon of paradigm shifts 
(Kuhn, 1962/1996). Such shifts occur when existing paradigms fail to account for explanation of phenomena, or for generation of new knowledge. Kuhn wrote about revolutionary science, for instance, Galileo, but Kuhn's ideas might be extended to social sciences and education as well. One could assert, for example, that Freud introduced a new paradigm in psychology to account for human behaviour. Others, though, would argue that Kuhn's notion of a paradigm shift applied only to the hard sciences and was not for the social sciences, as often suggested. Jackson's contribution to the field of education takes this tension into account.

The issue of dissemination and use of research knowledge is foundational to comprehending the influence of scholars on teaching and teacher education. Lauglo (1996) comprehensively reviewed the dissemination of educational research knowledge. He maintained that "there are differences among different fields in how knowledge is ... used' (Lauglo, 1996, p. 1). For example, there is 'internal' and 'external' dissemination and their relationships to the use of research knowledge. Internal dissemination and use typically takes place in networks that are intensely personal whereas external dissemination in social research takes place in many ways (Husén, 1988; Kogan, 1984; Kogan \& Hanney, 1999; Weiss, 1995). Lauglo (1990) stressed that the external spreading of ideas does not necessarily have to shape specific practices of education, though it might very well do. He explained that:

... research [also] has other very important uses ... It trickles into the cognitive maps of what is problematic and what may be taken for granted, into the kinds of questions which are recognized as important (Lauglo, 1990, p. 3).

He continued:

In addition to the historical influence of some of 'the great ideas,' some of the more ordinary research knowledge can exert influence by passing into the very language that is used when issues are defined and policies justified (Lauglo, 1990, p. 4).

In reading about research dissemination of educational ideas, we wondered how Jackson's ideas spread? Also, what was the 'life cycle' of his ideas from birth to decline? Like Ben-Peretz and Craig (2018), we join Lauglo (1996) in pondering the following research queries: 'What are the patterns of dissemination of research among researchers and among institutions? Whose research reaches most widely, is most widely read and most widely quoted and used by others?' (Lauglo, 1996, p. 1). These questions also seemed salient in our enquiry into the impact of Philip W. Jackson's scholarship.

\section{Research method}

This teaching and teacher education enquiry is an "[i]nquiry into [i]nquiry" as Schwab (1962) would describe it. The methodological rationale is outlined in Schwab's (1962) Inglis Lecture on how scientists think. Schwab focused not only about how people think using enquiry but also about how people do enquiry and conduct research via the enquiry method (Connelly, 2013). Schwab saw value in recursively reflecting on studies conducted in the past to glean additional lessons from them. He favoured 'serial interpretation' (Schwab, 1983) - enquiry undertaken across multiple studies and sources-to arrive at fresh interpretations of lived phenomena previously not held in dialectical tension with one another. He championed 'look[ing] across' (Clandinin, Caine, \& Lessard, 2018, p. 131) and 'thinking across' (Craig, 2009) investigations to arrive at deeper understandings of practices and contributions. So far, 'talking across' studies have spanned the disciplines and have addressed such topics as time (i.e. Duff, Hengst, Tranel \& Cohen, 2007), curriculum (i.e. Lytle \& Botel, 1990), culture (i.e. Richards, 1981), race (i.e. CicettiTurro, 2007), gender (i.e. Staeheli \& Nagar, 2002), languages (i.e. Hall, 1990), borders (i.e. Landau, 2007), differences (i.e. Flower, 2003), movements (i.e. Dixon, 2014), labour (i.e. Waterman, 2005), economies (i.e. Arthur, 2011), politics (Kling, 2017), paradigms (Woodward, 1996), and worlds (Forey \& Lockwood, 2010). Methodologically, this article falls in the looking across/thinking across/talking across genre of research unfurling in many fields in the social sciences and, as mentioned earlier, emulates a previous 
enquiry undertaken by Ben-Peretz and Craig. What we (Craig and Flores) do here is examine Jackson's contributions to teaching and teacher education over time and across areas of study. To address our chosen topic, we draw on multiple published works (original articles, books, article and book reviews) that arose in our survey of the literature as well as the targeted interviews we conducted. We also pull on material openly available on the internet and include other evidence such as AERA and university press releases, funding and award announcements and even his obituary. We then interweave our accumulated findings in multiple languages of communication to shed light on the nature and extent of Jackson's influence on the field of education and how the dissemination of his scholarship unfurled.

\section{Serial interpretation of Jackson's contributing topics of enquiry}

Our serial traversing of Jackson's scholarship and the work it spawned over time resulted in the identification of six noteworthy strands of his work having to do with: 1) a shift in research agenda and method of enquiry, 2) life in classrooms, 3) Deweyan philosophy, 4) use of poetry as a way of knowing, 5) hidden curriculum and 6) qualitative research.

\subsection{Shift in research agenda and method of enquiry}

Jackson's career trajectory was an ever evolving one. He began as a psychologist and maintained his appointment in the University of Chicago's psychology department despite his transitions from psychology to curriculum to philosophy (Shulman, 2007). At the beginning of his academic career, Jackson used his training in psychometrics in his experiments with J. W. Getzels. Together, they devised a statistical test to measure children's milestones. Their quantitative instrument provided evidence for the conclusion that high IQ, as measured by tests, is not a mark of giftedness. The New York Times (October, 1960) summed up their findings as follows: 'The truly creative child who thrives on novelty is likely to find IQ tests boring and hence do poorly on them.' (Abowd, 2015). To this day, this discovery is known as the Getzels-Jackson effect.

Philip Jackson's career did not continue in psychometric experimentation because his research agenda changed while he was on leave from the University of Chicago in 1962-1963. While working at the Centre for Advanced Study in the Behavioural Sciences at Stanford University (which was directed by the wellknown curriculum leader, Ralph Tyler), Jackson met a primate researcher who used behaviourist techniques to test and train baboons. Philip Jackson concluded that he was doing the same thing with children in his research studies; that is, 'treating them like animals in a behaviorist paradigm.' Jackson immediately realized there must be 'a better way to understand children, a better way than poking them with sticks' (David Hansen in Abowd, 2015). At the same time, Jackson was influenced by other anthropologists at the Centre who studied animal behaviour in more nuanced, context-bound ways. As a result, Jackson adopted an ethnographic style of research, which formed a new method of investigation in the field of education with Life in Classrooms being 'one of the first book-length studies in the history of educational research.' (Granger, Cunningham, \& Hansen, 2015, p. 2) Through mingling with the anthropologists, Jackson learned the significance of studying research participants' 'natural habits' and the importance of 'honing [one's own] perceptual abilities as an instrument[] of research.' (Granger et al., 2015, p. 2)

Jackson ceased conducting experiments with Getzels and declined an invitation to write a highly popular quantitative research methods textbook with Nathaniel 'Nate' L. Gage, a lucrative book that David Berliner subsequently co-authored. Jackson said he no longer believed that statistical instruments were the most powerful way to understand children and teachers (Jackson, AERA Narrative Research SIG Lecture, 2014). Also, on a practical level, he was acutely aware at the time that he needed a single-authored publication to be promoted at his institution. Upon returning to the University of Chicago, Jackson wrote Life in classrooms (Jackson, 1968) from an embedded researcher point of view. In it, he argued that classrooms are 'too complex an affair to be viewed or talked about from one single perspective ... all of the means of knowing at our disposal [should be used]' (Jackson, 1968, p. vii). The 
volume became a near-universal reading in university curriculum and teacher education courses throughout the world.

According to Walter Doyle (Doyle, personal communication, 2018), 'the 1970s divide in research essentially [played out] between followers of Nathaniel "Nate" L. Gage and followers of Philip Jackson.' Nathaniel L. Gage was an educational psychologist who had worked in the laboratory of B. F. Skinner (Sullivan, 2008). Gage (1963) promoted research on teaching as a science (Gage, 1978) and vigorously spread its influence in the field. A giant in the world of education, he had edited the 1962 Handbook of Research on Teaching and founded the journal, Teaching and Teacher Education, in 1985. On the other side of the debate was his friend, Philip Jackson (1992), whose preparation was also in statistical measurement and who had a theory named after him. Jackson would similarly edit a handbook, the 1992 Handbook of Research on Curriculum. However, unlike Nate Gage, Jackson had experienced a shift in research perspective. His experiences of classroom life, along with his view that researchers needed to 'face [their] ignorance' (Jackson, 1987), '[ended up being] the standard inspiration for alternate inquiry approaches into what went on in teachers' minds and spirits, as they prepared for, engaged with and reflected on events in and around their classroom practices' (Kompf \& Rust, 2013, p. 9). This idea is emphasized by many authors who have since been influenced by Jackson's work. Torres (1991b), for example, stressed the idea of understanding and discovering the mental processes and implicit theories that teachers possess about teaching. He added that the ethnographic research and intensive observation of classroom activities and interactions between students and teachers and many interviews and discussions with the participants that Jackson conducted became a key element distinguishing educational studies in an indelible manner.

\subsection{Qualitative research}

Our discussion of Philip Jackson thus far suggests that he not only broke educational ground substantively, but also methodologically through championing ethnographic and other qualitative methods of enquiry (i.e. grounded theory, narrative enquiry, etc.) after conferring with some anthropologists-in-residence at the Center. Jackson's AERA Presidential Lecture (Jackson, 1990) revolved around the different functions of educational research: decision making research (research paid by funding agencies) and conclusion making research (research conducted by researchers taking up their own questions about practice). 'Let our writing be as difficult as it has to be to deliver its message in full' was the pearl of wisdom that he left his audience members. But Jackson did not finish his keynote address there. He ended with a stanza of poetry that presaged a dazzling array of questions. He cited Yeats:

\footnotetext{
God guard me from the thoughts men think

In the mind alone;

He that sings a lasting song

Thinks in a marrow-bone. (Yeats, 1958, in Jackson, 1990)
}

Next came Jackson's queries and the profundity of his message:

\footnotetext{
These are words we all might take to heart. But how? What does it mean to do so ... ?

How does the educational researcher of all people think in a marrow-bone or dare even try? ... I call upon us all to answer this question today as best we can.
}

Jackson's provocation to 'think in the marrow bone' has confounded qualitative researchers as they engage in classroom-based research ever since. They wonder how they will find the time to engage in studies involving deep-thought, they ponder why their research genre is not more valued, and they question whether reviewers and publishing outlets will accept their against-the-grain research products, together with endless other queries, many having to do with the researcher as instrument. 
In 1993, Philip Jackson continued his discussion of the purposes and uses of research with his Qualitative Studies in Education article, 'Qualitative research and its public.' In this publication, he discussed who and what qualitative research was for. In his view, qualitative research is the genre of research that is 'discursive and belle lettristic in form'-meaning that is a kind of research involving beautiful writing that conveys rich meanings in its own right. Jackson pinpointed an issue that had challenged-and continues to challenge-qualitative researchers-even as their research genre has expanded exponentially and globally. He comforted his colleagues by urging them to 'not be sullen because [their] audiences are not large or that [they] are not attracting readers of a "certain type."' He drew parallels between the dissemination of qualitative research and dissemination in the literary field. He said he was reminded of the poet, Dylan Thomas, who stayed up late writing love poems

But for the lovers, their arms round the griefs of the ages.

They pay no praise nor pages.

Nor heed my craft or art ... (Thomas, 1938/2003, p. 134, in Jackson, 1993)

Jackson queried: 'Why then did Dylan Thomas continue burning the midnight oil writing love poems, knowing what he knew about the fickleness of the public?' In Jackson's view, Thomas answered his own questions - (and Jackson's puzzle as well) -in the final line of his first stanza: 'for the common ways of the most secret heart' (Thomas, 1938/2003, p. 134, in Jackson, 1993).

At his final AERA lecture (Jackson, 2014), Philip Jackson was asked to revisit his 1968 statement about 'classroom life ... [being] too complex an affair to be viewed or talked about from any single perspective [and] we must ... use all the ways of knowing at our disposal.' In the transcribed speech, Jackson replied that 'we must use our understanding of literature, of poetry, of music to help us see classroom life.' He continued by explaining:

Our focus on being must be played the way you play a musical instrument by lifting different fingers to get different notes. We must play the full organ of our songs as observers, as former students and remember what it was like for [us] to be a fourth grader. You know, to relive memories of schooling of our own and our own teachers. That's playing our songs like organs.

He continued:

I do not think that there is a formula for how to do that. But you can tell when people are brilliant. They ask even [better] questions when they are playing themselves.

He then reflected backward, saying 'Nate Gage-my dear, dear friend ... just got it wrong because he did not allow himself to be mystified by education ... and the only way you can do it is to allow your imagination to be exercised ...' To Jackson, Gage was not wrong in a good-bad sort of way, but wrong in the sense that his research stance and methods were too narrow (Boostrom, personal communication, 2018) for mystification to happen. Jackson was neither extolling mystery nor reifying confusion; he was simply calling for vulnerability and an open sense of wonder on the part of scholars. In texts generated over decades, Philip Jackson's defence and cultivation of qualitative research methods can be found. His work has influenced researchers internationally in finding out what is really going on in schools and classrooms. For instance, a study conducted in Chile in the early 1990s focusing on how secondary schools feed into a proposed school quality improvement programme, shows that what could have turned into a factual report on conditions and processes was in fact titled The school within: An ethnographic study of teaching practices in secondary education (Avalos, 2018, interview/personal communication). Avalos indicated that this study 'touched on a number of the topic areas addressed in Philip Jackson's Life in the Classrooms. ... Interactions of teachers with students and among students were often marked by humorous statements intended for laughter or to downgrade a situation, or to establish a bond of mutual understanding.' 


\subsection{Deweyan philosophy}

As mentioned, Philip Jackson became introduced to John Dewey's philosophy of education while attending college/university. From that point onward, Dewey formed a strong presence in Jackson's studies and his life. As mentioned, Jackson would later lead the nursery program and direct Dewey's Laboratory Schools at the University of Chicago. While heading up the Laboratory Schools, he searched for the bust of John Dewey that he knew was there because its partner sculpture was prominently displayed at Teachers College, New York. At the University of Chicago Laboratory Schools, Jackson found Dewey's bust in a storage closet. He immediately brought it back to his office. Later, a secretary turned Dewey's face to the wall because she was tired of him staring at her (Boostrom, personal communication, 2018). The story of the statue over time speaks metaphorically to the near disappearance of Dewey from the American educational scene. Dewey remains an icon, but few took his philosophy of experience seriously. One notable exception, among others, was Philip Jackson who told his students that he considered John Dewey to be the most important figure in his life other than his family members (Boostrom, personal communication, 2018). Eliot Eisner (2007) agreed that 'no one in the field of education ... had such a detailed and intimate grasp of Dewey, his life, his family, his context, his strengths, his weaknesses, his love affairs, his intellectual work... Dewey [was] firmly on Phil Jackson's back ...' (p. 158) Jackson honoured Dewey's lifelong contributions to his intellectual development by citing him in all of his scholarship as part of his research signature (Connelly, personal communication, 2018). Late in life, Jackson's son, David, asked his father whether the years he spent administering the Laboratory Schools was wasted time. Jackson replied that that experience provided him with rich understandings of schools that he would not otherwise have had and that those Deweyan-inspired meanings deeply enriched his thinking and his scholarship.

Over the course of his career, Philip Jackson became known as an internationally recognized expert on John Dewey particularly in the areas of aesthetics and metaphysics. To Jackson, Dewey's notion of aesthetics leads to 'enriched understandings of the experienced object, and ultimately to a deepened understanding of the self,' while the arts metaphysically 'reveal what more of life could be like [and] what we ourselves could be ... if we really worked at it.' (Granger et al., 2015, p. 3). Jackson wrote three widely praised books on Dewey's philosophy of education: John Dewey and the Lessons of Art (Jackson, 1998), John Dewey and the Philosopher's Task (Jackson, 2002) and What is Education? (Jackson, 2011). He also served as president of the John Dewey Society from 1996-1998 and delivered the AERA John Dewey Lecture in 1999. In What is Education?, a volume that won the coveted PROSE award given annually by the Professional \& Scholarly Publishing Division of the Association of American Publishers (Michael Connelly, personal interview, 2018), Jackson (2011) contemplated Dewey's statement:

I do not wish to close without recording my firm belief that the fundamental issue is not of new versus old education nor of progressive against traditional education but a question of what anything whatever must be to be worthy of the name education.

Like Dewey, Jackson transcended bifurcations between traditional education and experience-based education and his own distinctions between mimetic curriculum and transformative education, which themselves 'echo[d] the history of ideas' (Greene, 2007, p. 53), to examine the fundamental purpose of education, which he summarized in this way:

Education is a socially facilitated process of cultural transmission whose explicit goal is to effect an enduring change for the better in the character and psychological well-being (the personhood) of its recipients and, by indirection, in their broader social environment, which ultimately extends to the world at large. (Jackson, 2011, p. 95)

Jackson's questioning and rigorous enquiry into this phenomenon cultivated a renewed meaning of education in him and further cultivated his embracing of

... Dewey's focus on experience, particularly the idea that you can't keep piling things onto children, like pouring things down a funnel. You need to engage them in experiences in the classroom that allow them to take intellectual ownership and to see learning as alive and dramatic and vivid. (Hansen in Abound, 2015) 


\subsection{Poetry as amorphous experience}

If citing John Dewey in his works was part of Philip Jackson's research signature, so, too, was Jackson's inclusion of stanzas of poetry part of his trademark. According to his students (Hansen, Driscoll, Arcilla, \& Jackson, 2007), poems were Jackson's 'essential way of knowing the world.' They served as a vehicle that enabled him to 'work through intellectual problems' (p. 2). . Like Robert Frost (1939/1972), Jackson profoundly understood how poetry 'begins in delight and ends in wisdom' (p. 394). Also, Jackson had a knack of deftly integrating verse into his scholarship, imbuing it with an invitational quality of 'you come, too,' as Robert Frost (1917) aptly phrased it in The pasture.

A prime example was Jackson's linking of William Butler Yeats' poem, Among school children, with his 'life in classrooms' research, particularly the following lines, which seemed autobiographical for both Yeats and Jackson:

I walk through the schoolroom questioning ...-the children's eyes

In momentary wonder stare upon a sixty-year-old smiling public man (Yeats, 1933/1961).

Furthermore, Jackson seemed to echo Yeats' question of 'How can we know the dancer from the dance?' because Jackson in Life in classrooms was ultimately asking: 'How can we know the teacher from the teaching?' Jackson intimately understood that teachers necessarily bring themselvestheir personalities and their foibles-as well as their knowledge, skills and dispositions to the act of teaching. Through poetic allegory, he deftly brought this knowing to his readers' attention.

In a similar way, he used stanzas of poetry to critique others' positions. In 2001, the No Child Left Behind (NCLB) Act was instituted in the United States (No Child Left Behind [NCLB], 2002). That act replaced prior Elementary and Secondary School legislation with a high stakes accountability policy. The approach made winners and losers of children and pitted teachers against one another through making them compete for pay-for-performance bonuses determined by value-added evaluation procedures - at least in the United States. Consequently, the fields of curriculum, teaching and teacher education face serious challenges, many stemming from the fact that Dewey's theory of experiential education lost (despite Jackson's and many others' championing of it) and the behaviourism perpetuated by Skinner, Gage, Thorndike and others won and currently controls the field (Lagemann, 2002). At the time of the Division B meeting, the curriculum field was deeply divided. Division B had been taken over by reconceptualists whose research agendas did not impress Philip Jackson. When the reconceptualists declared that they would abandon research with teachers in schools until the effects of NCLB Act had subsided, Philip Jackson became disgruntled. While he also was concerned about what was happening in schools and to teachers and students, he wanted the research community to move beyond claims of good and evil educational practices and policies. Earlier, he had cited Noam Chomsky, who said 'the schools have taken quite a beating in recent years and I do not wish to join in the pummeling ... but ...' (Jackson, 1977). Like Chomsky, Jackson felt that researchers needed to develop 'a curious mix of doubt and hope in their hearts' (Jackson, 1977, p. 329) as they go about their work even in contested times. Retreating from the schools, for Jackson, was not an act borne out of hope. Jackson was crystal clear about his disdain for the NCLB policy and the reconceptualists' chosen approach, saying the 'hidden curriculum' no longer was hidden and that he 'did not like [the term] anymore' because others (including the reconceptualists) had given it a 'malevolent character' (Boostrom, personal communication, 2108), causing it to be associated with 'deliberate attempts to miseducate students' (Boostrom, personal communication, 2018). At the meeting, Philip Jackson went on to liken reconceptualists to 'scorners,' reciting a stanza from William Blake's (1990) poem, The Scoffers, which drew on Proverbs 3:34, 'He mocks those who mock, but gives grace to the humble.' 
Mock on, mock on, Voltaire, Rousseau,

Mock on, mock on; 'tis all in vain;

You throw the sand against the wind

And the wind blows it back again. (Blake, 1893, p. 108)

At the same time, Philip Jackson implied that what the reconceptualists and others would see if they observed classrooms and schools could be revelatory-or in Blake's (1990) belle lettristic phraseology 'gem[s] reflected in the beams divine.'

\subsection{Classroom life}

Jackson established himself as a curriculum scholar through authoring The practice of teaching in 1986 and editing AERA's Handbook of Research on Curriculum in 1992 (AERA, 2015). Jackson (1986) spoke of classrooms as 'deceptively simple' citing Erasmus who wrote: 'In the opinion of fools it is a humble task ... But in fact it is the noblest of occupation.' As can be seen, Jackson had an uncanny ability to draw attention to 'what does not scream out at you and to reveal through language its presence and meaning' (Eisner, 2007, p. 156).

According to Linda Darling Hammond (2007), those reading Life in classrooms are left with the lasting image of teachers' work resembling butterflies, not bullets. As Jackson argued in his 1968 classic,

Teaching is an opportunistic process. Neither the teacher nor the students can predict with any certainty exactly what will happen next. Plans are forever going awry and unexpected opportunities for the attainment of educational goals are constantly emerging .... (...) the path of educational progress more closely resembles the flight of a butterfly than the flight of a bullet (p. 67).

Professor Emeritus Robert Dreeben, Jackson's colleague at the University of Chicago for more than three decades, further emphasized:

It is greatly to [Philip Jackson's] intellectual credit that he began to look at classrooms and teaching in a more holistic and imaginative way-one that, among other things, paid attention to the tacit messages that emanated from classrooms and from teachers' work, matters that had been long ignored (Dreeben in Aboud,2015).

His work also has had an important impact internationally. In his Foreword to the Spanish translation of Jackson's book Life in Classrooms (La vida en las aulas, published by Morata in 1991), Torres (1991a) underlined that P. W. Jackson was one of the first researchers that really looked into what teachers have to say about their work and all that happens inside classrooms; hence, making it possible to see teaching as a much more complex activity than it is sometimes appears. He also stressed that Jackson was one of the first to advocate for the enhancement of the understanding of teaching. For example, in 1988, with funding from the Spencer Foundation, Jackson launched a multi-year, field-based research study exploring the role of schools in children's moral development. Jackson, Hansen and Robert Boostrom (the latter two being doctoral students at the time) observed the classrooms of 18 teachers from six public and private neighbourhood schools for five years and brought them together twice a month for dinner followed by openended discussions. Hansen recounted:

Phil was interested in the positive human influence that the person in the role of teacher can have ... The discussions were just extraordinary - they were about whatever the teachers wanted to talk about, the most significant and human aspects of being a teacher, the challenging moments and the beautiful moments. (Hansen in Abowd, 2015)

In Latin America, research in Bolivia, Chile, Colombia and Venezuela has been longitudinally influenced by the way Jackson acknowledged the struggles and tensions associated with 'the daily grind of teaching' (Jackson, 1968, p. 1) with which teachers wrestle in their everyday lives. The grind further extends to the implementation of ongoing school reforms. Beatrice Avalos noted that 
the [aforementioned Latinx] studies derived in a way from approaches in Jackson's Life in the Classrooms and were carried out over thirty years ago. But they are relevant today. Not so much on account of the specifics of the contexts documented, but in the face of new pressures on teachers and students brought about by social change and policy emphases on accountability and competitiveness. (Avalos, 2018, interview/personal communication).

Once again, we see Philip Jackson changing not only how teaching was researched, but also the methods of enquiry through which teachers were studied in Latin America as well.

\section{Overarching themes}

Overall, three themes emerged from the six targeted areas having to do with the scholarship of Philip W. Jackson: 1) the influence of Jackson's ideas and approaches, (2) Jackson's direct impact through involvement in projects/organizations, and (3) Jackson's impact on the scholarly literature. A synopsis of the discussion follows.

\subsection{Influences of Jackson's ideas and approaches}

Philip W. Jackson forms a role model of how fluid enquiry can be undertaken. He joined Charles Judd and John Dewey (also of the University of Chicago) in being among the first researchers ever to go into schools, to observe teachers and students interacting with one another around subject matter, and to record what took place in classroom settings in the words and feelings of those experiencing curriculum as it became lived. Through his close readings of life in classrooms, Jackson demonstrated the power of illuminative enquiry. As Eisner (2007) rhetorically put it: 'Who can forget "the daily grind"? Who can forget the importance of students learning how to delay gratification? Who can forget the aroma, or should I say odor, of a place that smells of stale milk and that leaves chalk dust on your sleeves?' Jackson's landmark book confirmed in graphic language his preference for finding out 'what actually happens in classrooms' rather than pontificating (as he believed others were doing) about 'what ought to happen.' It also communicated his unswerving belief that classrooms are 'too complex an affair to be viewed or talked about from one single perspective... All the means at our disposal [should be used]' (Jackson, 1968, p. vii). Furthermore, his influence on the understanding of the ecology of the classroom and its peculiar features is illustrated in many ways and in a variety of contexts. As Miriam Ben-Peretz from Israel asserted,

The work of Philip Jackson is outstanding because of his interest in people, their dreams, concerns, ways of thinking and doing, as well as the interactions between teachers and their students. The title of his book, Life in classrooms, reminds us that classrooms are one of the most important environments for both students and teachers, who spend large parts of their days in classrooms and preparing for classrooms. Classrooms constitute a special eco-system, which exists all over the world. As such, it is worthy of in-depth study and Jackson's work is a beautiful example of such studies." (Ben-Peretz, 2018, personal communication/interview).

Similarly, Linda Darling Hammond (2007) connected Jackson's work to the 'understanding of learning as grounded in experience and an understanding of teaching as a complex, reciprocal process of connecting students' many experiences with the goals of curriculum' (pp. 16-17).

\subsection{Jackson's direct impact through involvement in projects/organizations}

Jackson's efforts to keep John Dewey's philosophy alive through his work in the John Dewey Society and his presidency of the American Educational Research Association are widely recognized. His contributions to the curriculum field are also evident in his editorship of the official AERA 1992 Handbook of Research in Curriculum. However, it was his ongoing defence of teachers and schools that is particularly worthy of mention. 
Table 1. Philip Jackson's books and citations.

\begin{tabular}{lcc}
\hline Book title & Publication year & Citations \\
\hline Creativity and Intelligence & 1962 & 2727 \\
Life in Classrooms & 1968 & 6687 \\
The Practice of Teaching & 1986 & 732 \\
From Socrates to Software: & 1989 & 12 \\
$\quad$ The Teachers as Text and the Text as Teacher & & \\
Handbook of research on curriculum & 1992 & 474 \\
The Moral Life of Schools & 1993 & 812 \\
John Dewey and the Lessons of Art & 1998 & 573 \\
John Dewey and the Philosopher's Task & 2002 & 53 \\
What is Education? & 2011 & Not tallied \\
\hline
\end{tabular}

\subsection{Jackson's impact on the scholarly literature}

By today's standards, Jackson's scholarly productivity would be considered average. According to Scopus (13 August 2019), he has 30 publications, 430 citations and an h-index of 11. What Scopus did not include in its statistical analysis were his books-all 9 of them-with Life in classrooms being cited by Google Scholar over 6500 times (13 August 2019) (Table 1) Philip Jackson epitomized the enduring 'need to question' (Boostrom, personal communication, 2018), a quality that distinguished his life and career.

Not included here is how Jackson's work influenced knowledge and research on teachers and teaching in ineffaceable ways internationally. Beatrice Avalos from Chile explained this lasting effect that rippled around the world:

In re-reading the introduction to this marvellous book written so long ago (it seems) one is surprised at the subtle way in which Philip Jackson described the pedagogy and social relations in US classrooms. He moved the usual educator's attention away from simple straightforward descriptions about classroom events, so close to the behaviourist approaches of the time, to the nature of social interactions, perceptions, emotions and assumptions underlying the organization, order and relationships in primary school classrooms. It took some time for such an approach to reach the attention of school and classroom researchers both in the US and England (Lortie's Schoolteacher was published in 1976; Delamont's Interaction in the Classroom also appeared in 1976). And when it really did, it was when ethnography and other qualitative observational analysis of teaching situations gained prominence, influencing new forms of educational research expressed today in many journals and research articles. (Avalos, 2018, interview/personal communication).

Here, Avalos connects qualitative research as an identifiable research method (some would say paradigm) directly to Philip Jackson, a taken-for-granted notion in the current research milieu.

\section{Significance and conclusion}

Our cumulative analysis reveals how Jackson's 'unit ideas'-'life in classrooms', 'hidden curriculum' and 'qualitative research methods'-flourished in the field of education over a continuum of time. Jackson's core ideas were kept alive through those who had personal contact with him, his colleagues and students, as well as internationally and in the following generation through the research literature and word-of-mouth. When we triangulated the various pieces of evidence we collected, we found congruity between what his students shared in the tribute volume and articles they wrote in his honour, what we found in our literature search, and what others nationally and internationally shared in interviews with us.

\subsection{Generative scholarship}

Philip W. Jackson's deeply embedded work on the concept of the 'hidden curriculum' ensures that his scholarship remains in the bloodstream of the field of education. Although the Wikipedia page dedicated to the 'hidden curriculum' does include Jackson's name alongside a series of others, with 
some of those others being 'radical educators,' whose definitions of hidden curriculum differ substantially from Jackson's own version. This state of affairs attests to a feature of the history of ideas; namely, how an idea can be radically transformed in the light of new interests.

\subsection{Intergenerational legacy}

Concerning the intergenerational impact of Philip W. Jackson's scholarship, several modes of influence are discernable: the first, and probably the most straightforward, is the passage of ideas from teacher to student, which is repeatedly exemplified in the chapters contained in the Hansen et al. (2007) book and in the other articles authored by his students. Hlebowitsh (2005) states that he additionally found 'the idea of generations useful because fields are built by generations of thinking' (p. 120). Hlebowitch explained that 'The generations speak, as in conversation, to us, showing us our common project and reminding us that no person is an island' (Hlebowitsh, 2005, p. 122). This most certainly is the case where Jackson's intergenerational legacy is concerned.

\subsection{Scholarly influence}

Jackson's scholarship has spread via the academic literature. It is important for us to note-as BenPeretz and Craig (2018) before us did-that dialogue, confrontation, criticism and difference of opinion, not simply appreciation, are all tools in keeping scholarship alive, with 'the net outcome of a good discussion [being] the advancement of understanding' (Hlebowitsh, 2005, p. 119). Beyond direct and indirect influence of scholars, there exists charisma, which Jackson definitely had when he faced Gage during in the 'paradigm wars' (Husén, 1988; Lincoln \& Guba, 1985). Clearly, Jackson's magnetism attracted others to him. His student, David Hansen, noted: 'I think he'll be remembered by every single educator who met him as an extraordinary, brilliant and passionate person ... He was a force of nature, a man full of life.' AERA President Jeannie Oakes circulated the following statement upon Philip Jackson's death:

Phil's intellect and quest for knowledge shaped our field, both substantively and methodologically, as he recognized and explained the intertwining of the technical and moral dimensions of learning and schooling. That contribution is huge. But we also celebrate Phil's incredible goodness as a human being and his deep caring for education, research, and those of us who were lucky enough to have known him (AERA, 2015).

And the John Dewey Society concluded:

\footnotetext{
Jackson was, more than anything else, a man with a remarkable commitment to serving the enterprise of education through wrestling with conceptual truths. He sought, through his research, writing, and teaching, to "effect an enduring change for the better" in everyone associated with education: teachers, students, administrators, and researchers. He was a brilliant, generous, and wise man, who has left us with an inspirational legacy for reforming not only education, but "the world at large."
}

As repeatedly emphasized in this article, Philip W. Jackson was a polymath with a wide range of intellectual interests and sympathies, including engagement with teaching and administration, quantitative and qualitative methods, psychology and philosophy, poetry and the arts. As an educator, he managed to irrevocably change how the field situates teachers' work, conducts research within teaching contexts and how researchers use themselves as sources of ideas and research instruments. Studying Jackson's influence and impact nationally and internationally further contributes to the knowledge base of education.

\section{Note}

1. As an aside, Michael Apple, another distinguished figure in the curriculum field, graduated from the same teachers' college as Philip Jackson. 


\section{Disclosure statement}

No potential conflict of interest was reported by the authors.

\section{Notes on contributors}

Cheryl J. Craig is a Professor and Houston Endowment Endowed Chair of Urban Education at Texas A\&M University. She is an American Educational Research Association (AERA) Fellow, a recipient of AERA's Division B (Curriculum) Award for her lifetime career achievements and a winner of AERA's Michael Huberman Award for her Outstanding Contributions to Understanding the Lives of Teachers. She has also received ISATT's STA ${ }^{2} \mathrm{R}$ award for her exemplary contributions through research, teaching and service to the international field of teaching and teacher education.

Maria Assunção Flores is an Associate Professor with qualifications at the University of Minho, Portugal. She is Editorin-Chief of the European Journal of Teacher Education and Executive Editor of Teachers and Teaching: Theory and Practice in addition to being the past-Chair of the International Association on Teachers and Teaching (ISATT) (20132019). She recently was the first in Portuguese history to receive the Research Award from the International Council on Education for Teachers (ICET), one of the most distinguished global honors in the field of education.

\section{ORCID}

Cheryl J. Craig (iD) http://orcid.org/0000-0002-3190-9116

Maria Assunção Flores (iD) http://orcid.org/0000-0002-4698-7483

\section{References}

Abowd, M. (2015, July 31). Philip W. Jackson, education scholar, committed to children's flourishing, 1928-2015. UChicago News. Retrieved from https://news.uchicago.edu/story/philip-w-jackson-education-scholar-committedchildrens-flourishing-1928-2015

American Educational Research Association E-Newletter. (2015, August). Past President Philip Jackson dies. Retrieved from http://www.aera.net/Newsroom/AERA-Highlights-E-newsletter/AERA-Highlights-August-2015/Past-PresidentPhilip-Jackson-Dies

Arthur, W. B. (2011). The second economy. McKinsey Quarterly, 4, 90-99.

Ben-Peretz, M., \& Craig, C. (2018). Intergenerational impact of a curriculum enigma: The scholarly impact of Joseph J. Schwab. Educational Studies, 44(4), 421-448.

Blake, W. (1893). The scoffers. In Poems of William Blake. New York, NY: Charles Scribner's Sons.

Cicetti-Turro, D. (2007). Straight talk: Talking across race in schools. Multicultural Perspectives, 9(1), 45-49.

Clandinin, D. J., Caine, V., \& Lessard, S. (2018). The relational ethics of narrative inquiry. New York, NY: Routledge.

Connelly, F. M. (2013). Joseph Schwab, curriculum, curriculum studies and educational reform. Journal of Curriculum Studies, 45(5), 622-639.

Craig, C. (1992). Coming to know in the professional knowledge context: Beginning teachers' experiences. Unpublished dissertation. Edmonton, CA: University of Alberta.

Craig, C. (2006). Why is dissemination so difficult? The nature of teacher knowledge and the spread of curriculum reform. American Educational Research Journal, 43(2), 257-293.

Craig, C. (2009). Trustworthiness in self-study research. Self-study Research Methodologies for Teacher Educators, 7, 21-34.

Cunningham, C. (2015). Beyond poking the chimp with a stick: A tribute to Philip W. Jackson (1928-2015) John Dewey Society http://www.johndeweysociety.org/wp-content/uploads/2015/08/A-Tribute-to-Philip-W-Jackson-by-CraigCunningham.pdf

Darling Hammond, L. (2007). Images of teaching: Cultivating a moral profession. In D. Hansen, M. Driscoll, R. Arcill, \& P. Jackson (Eds.), A life in classrooms: Philip W. Jackson and the practice of education (pp. 16-34). New York, NY: Teachers College Press.

Dixon, C. (2014). Another politics: Talking across today's transformative movements. Los Angeles, CA: University of California Press.

Duff, M., Hengst, J., Tranel, D., \& Cohen, N. (2007). Talking across time: Using reported speech as a communicative resource in amnesia. Aphasiology, 21(6-8), 702-716.

Eisner, E. (2007). Finding Phil. In D. Hansen, M. Driscoll, R. Arcill, \& P. Jackson (Eds.), A life in classrooms: Philip W. Jackson and the practice of education (pp. 153-160). New York, NY: Teachers College Press.

Erdman, D., \& Bloom, H. (1990). The poetry and prose of william blake. New York, NY: Doubleday. 
Flores, M. A. (1997) Problemas e necessidades de apoio/formação dos professores principiantes (Um estudo exploratório, Master Degree Dissertation). University of Minho, Portugal.

Flower, L. (2003). Talking across difference: Intercultural rhetoric and the search for situated knowledge. College Composition and Communication, 55(1), 38-68.

Forey, G., \& Lockwood, J. (Eds.). (2010). Globalization, communication and the workplace: Talking across the world. London, UK: A\&C Black.

Frost, R. (1917). Selected poems of robert frost. London, UK: Constable.

Fuhrman, S. (1994). Uniting producers and consumers: Challenges in creating and utilizing educational research. In T. Tuijnman (Ed.), Educational research and reform: An international perspective (pp. 133-147). Washington, DC: US Department of Education.

Gage, N. L. (1963). Paradigms for research on teaching. In N. L. Gage (Ed.), Handbook of research on teaching (pp. 94-141). Chicago: Rand-McNally.

Gage, N. L. (1978). The scientific basis of the art of teaching. New York, NY: Teachers College Press.

Granger, D., Cunningham, C., \& Hansen, D. (2015). Philip W. Jackson, December 2, 1928-July 21, 2015, A life well lived. Education and Culture, 31(2), 1-7.

Greene, M. (2007). Philip Jackson and the nuances of imagination. In D. Hansen, M. Driscoll, R. Arcill, \& P. Jackson (Eds.), A life in classrooms: Philip W. Jackson and the practice of education (pp. 51-59). New York, NY: Teachers College Press.

Hall, C. (1990). Managing the complexity of revising across languages. TESOL Quarterly, 24(1), 43-60.

Hansen, D., Driscoll, M., Arcilla, R., \& Jackson, P. W. (2007). A life in classrooms: Philip W. Jackson and the practice of education. New York, NY: Teachers College Press.

Hemsley-Brown, J., \& Oplatka, I. (2005). Bridging the research-practice gap: Barriers and facilitators to research use among school principals from England and Israel. International Journal of Public Sector Management, 18(5), $424-446$.

Hlebowitsh, P. S. (2005). Generational ideas in curriculum: A historical triangulation. Curriculum Inquiry, 35(1), $73-87$.

Huberman, A. M. (2002). Moving towards the inevitable: The sharing of research in education. Teachers \& Teaching: Theory \& Practice, 8(3-4), 257-268.

Husén, T. (1988). Research paradigms in education. Interchange, 19(1), 2013.

Jackson, P. (2014). Invited lecture. Narrative Research Special Interest. American Educational Research Association.

Jackson, P. W. (1968). Life in the classrooms. New York, NY: Rinehart and Winston.

Jackson, P. W. (1977). Beyond good and evil: Observations on the recent criticism of schooling. Curriculum Inquiry, 6(4), 311-329.

Jackson, P. W. (1986). The practice of teaching. New York, NY: Teachers College Press.

Jackson, P. W. (1987). Facing our ignorance. Teachers College Record, 88(3), 384-389.

Jackson, P. W. (1990). The functions of educational research. Educational Researcher, 19(7), 3-9.

Jackson, P. W. (1991). La vida en las aulas. Madrid: Morata.

Jackson, P. W. (1992). Conceptions of curriculum and curriculum specialists. In P. Jackson (Ed.), Handbook of curriculum research (pp. 3-40). New York: Macmillan.

Jackson, P. W. (1998). John Dewey and the lessons of art. New Haven, CT: Yale University Press.

Jackson, P. W. (2002). John Dewey and the philosopher's task. New York, NY: Teachers College Press.

Jackson, P. W. (2011). What is education? Chicago, IL: University of Chicago Press.

Jackson, P. W., Boostrom, R., \& Hansen, D. (1993). The moral life of schools. Thousand Oaks, CA: Jossey-Bass.

Kling, A. (2017). The three languages of politics: Talking across the political divide. Washington, DC: Cato Institute.

Kogan, M. (1984). School governing bodies. Portsmouth, NH: Heinemann Educational Books.

Kogan, M., \& Hanney, S. (1999). Reforming higher education. London, UK: Jessica Kingley Publisheres.

Kompf, M., \& Rust, F. (2013). The international study association on teachers and teaching (ISATT): Seeing tracks and making more. In C. Craig, P. Meijer, \& J. Broeckmans (Eds.), From teacher thinking to teachers and teaching: The evolution of a research community. Advances in research on teaching (Vol. 19, pp. 3-38). Bingley, UK: Emerald Publishing.

Kuhn, T. S. (1962/1996). The structure of scientific revolutions. Chicago, IL: University of Chicago Press.

Landau, L. B. (2007). Can we talk and is anyone listening-reflections on IASFM 10, Talking across borders: New dialogues in forced migration. Journal of Refugee Studies, 20, 335.

Langemann, E. (2002). An elusive science: The troubling history of educational research. Chicago, IL: University of Chicago Press.

Lauglo, J. (1990). Factors behind decentralization in education systems: A comparative perspective with special reference to Norway. Compare: A Journal of Comparative and International Education, 20(1), 21-39.

Lauglo, J. (1996). Banking on education and the uses of research: A critique of world bank priorities and strategies for education. International Journal of Educational Development., 16(3), 221-235.

Lincoln, Y., \& Guba, E. (1985). Naturalistic inquiry. Thousand Oaks, CA: Sage Publishing.

Lovejoy, A. (1940). Reflections on the history of ideas. Journal of the History of Ideas, 1, 3-23.

Lytle, S., \& Botel, M. (1990). The Pennsylvania framework for reading, writing, and talking across the curriculum: PCRP II. Harrisburg, PA: Pennsylvania Department of Education. 
No Child Left Behind Act of 2001. (2002). No Child Left Behind P.L. 107-110, 20 U.S.C. § 6319.

Palmer, J. (Ed.). (2001). Fifty modern thinkers on education: From Piaget to the present day (pp. 73-78). New York: Routledge.

Reid, W. (1993). Does Schwab improve on Tyler? A response to Jackson. Journal of Curriculum Studies, 25(6), 499-510. Richards, J. (1981). Talking across cultures. Canadian Modern Language Review, 37(3), 572-582.

Schwab, J. (1983). The practical 4: Something for curriculum professors to do. Curriculum Inquiry, 13(3), $239-265$.

Schwab, J. J. (1962). The teaching of science as enquiry. In J. J. Schwab \& B. Brandwein (Eds.), The teaching of science (pp. 3-103). Cambridge, MA: Harvard University Press.

Shulman, L. (2007). The impossible fullness of the empty classroom. In D. Hansen, M. Driscoll, R. Arcill, \& P. Jackson (Eds.), A life in classrooms: Philip W. Jackson and the practice of education (pp. 7-15). New York, NY: Teachers College Press.

Staeheli, L. A., \& Nagar, R. (2002). Feminists talking across worlds. Gender, Place and Culture: A Journal of Feminist Geography, 9(2), 167-172.

Sullivan, K. (2008, August 22). Nathaniel Gage, 'giant among educational researchers,' dead at 91. Stanford Report. https://news.stanford.edu/news/2008/september10/gage-091008.html

Torres, J. S. (1991a). Prologo a la edición española. La práctica reflexiva y la comprensión de lo que acontece en las aulas (pp. 11-26). Madrid: Morata.

Torres, J. S. (1991b). El curriculum oculto [The Hidden Curriculum]. Madrid, ES: Morata.

Waterman, P. (2005). Talking across difference in an interconnected world of labor (pp. 141-162). Boulder, CO: Rowman \& Littlefield.

Weiss, R. (1995). Learning from strangers: The art and method of qualitative interview studies. New York, NY: Simon and Schuster.

Woodward, M. R. (1996). Talking across paradigms: Indonesia, Islam, and orientalism. In Woodward M. R. (Eds.), Towards a new paradigm: Recent developments in Indonesian Islamic thought. Tempe, AZ: Arizona State University.

Yeats, W. B. (1933/1961). Among school children. In The poems of W. B. Yeats: A new edition. London, UK: Macmillan Publishing Company. 